\title{
Meningkatkan Hasil Belajar Siswa Melalui Metode Diskusi Pada Mata Pelajaran PKn Tentang Menghargai dan Menaati Keputusan Bersama pada Kelas VII SMP Negeri 3 Palopo
}

\author{
Hamriati Sahruddin
}

SMP Negeri 3 Palopo

hamriati03@gmail.com

\section{Abstrak}

\begin{abstract}
Upaya peningkatan Pembelajaran PKn pada konsep menghargai dan menaati keputusan bersama bertolak dari kenyataan di lapangan dan hasil wawancara dengan guru PKn sekaligus guru kelas VII SMP Negeri 3 Palopo Kota Palopo. Penguasaan materi oleh siswa masih sangat kurang, dibuktikan nilai awal yang didapat murid sebelum penelitian adalah $20 \%$ murid memperoleh ketuntasan belajar. Berdasarkan hal tersebut maka penelitian ini difokuskan pada mata PKn pada konsep menghargai dan menaati keputusan bersama dalam dua sub pokok bahasan tata tertib sekolah dan tata tertib kelas dengan menggunakan metode diskusi. Tujuan penelitian ini untuk meningkatkan hasil pembelajaran PKn pada konsep menghargai dan menaati keputusan bersama dalam konsep tata tertib sekolah dan tata tertib kelas dengan menggunakan metod diskusi. Pendekatan yang digunakan yaitu pendekatan kualitatif dengan rancangan penelitian tindakan. Rancangan penelitian ini di susun dengan satuan siklus secara berdaur ulang berulang meliputi (1) perencanaan, (2) pelaksanaan, (3) observasi, (4) refleksi. Hasil penelitian menunjukan bahwa penggunaan metode diskusi yang terdiri dari enam tahap yaitu (1) tahap pembangkitan semangat belajar , (2),tahap pambagian kelompok (3) tahap ekplorasi dengan bertukar pikiran antar sesama murid dan guru, (4).tahap mengaitkan pembelajaran dengan realitas kenyataan lingkungan murid (5) tahap kesimpulan (6) tahap penilaian. Akan dapat meningkatkan kemampuan pada bidang studi PKn, konsep menghargai dan menaati keputusan bersama dalam dua sub pokok bahasan tata tertib sekolah dan tata tertib kelas Murid kelas VII SMP Negeri 3 Palopo.
\end{abstract}

Kata Kunci: diskusi, keputusan bersama, pembelajaran PKn

\section{Pendahuluan}

Pelaksanaan proses pendidikan di SMP terdiri dari beberapa mata pelajaran salah satunya adalah mata pelajaran Pendidikan Kewarganegaraan (PKn). Mata pelajaran PKn pada dasarnya adalah untuk membantu mengembangkan pendidikan pembelajaran dalam meningkatkan moral murid di sekolah. Agar memperoleh moral yang diharapkan dari setiap murid di sekolah, tingkah laku anak sekolah sering membuat kesal gurunya. Misalnya, tidak menghargai guru dan teman-temannya serta tidak mau berdisiplin dengan apa yang telah disepakatinya, baik itu dalam mematuhi aturan yang dibuat oleh sekolah maupun aturan kelas yang nantinya berdampak besar pada ketidak patuhan pada aturan keluarga hal ini disebabkan kebanyakan murid tidak memahami konsep pembelajaran secara benar dan aplikasi konsep tersebut di dalam masyarakat. 
Pembelajaran Pkn pada siswa SMP bertujuan untuk mengembangkan potensi yang dimiliki murid, memiliki kekuatan spiritual keagamaan, pengendalian diri, kepribadian dan akhlak yang mulia terpancar pada sikap dan perilaku sehari-hari murid SMP. Oleh sebab itu, dalam pendidikan menuntun dan mengarahkan anak dalam hidupnya dan masa pertumbuhan dan perkembangan. Jadi tujuan utama pembelajaran PKn dalam peningkatan moral adalah kedisiplinan dan pemahaman konsep yang benar dengan memberikan pola tingkah laku yang baik nantinya dalam bermasyarakat, yang tak lepas dari sikap, etika, nilai-nilai moral Pendidikan Kewarganegaraan.

Salah satu kajian yang tercamtum dalam Kurikulum Tingkat Satuan Pendidikan (KTSP) dalam pembelajaran PKn, yang terdapat di SMP kelas VII, dalam hal ini mengenai peningkatan hasil belajar. Dapat diwujudkan dengan penelahaan konsep PKn yang benar yaitu tentang menghargai dan menaati keputusan bersama, baik dalam bentuk sikap dan konsep-konsep yang benar sehingga dapat berimplikasi pada hasil pembelajaran, karena mata pelajaran PKn masih sangat luas dan memerlukan banyak pengembangan konsep. sehingga penggunaan metode yang tepat dapat memudahkan pembelajaran untuk diterapkan.

Dari Observasi awal pembelajaran PKn yang dilaksanakan di kelas, peneliti memperoleh informasi sebagai berikut sebagai berikut: (1) guru dalam mengajarkan konsep pada mata pelajaran PKn kepada murid kurang melibatkan murid secara aktif dalam interaksi belajar mengajar sehingga murid kurang termotivasi dalam belajar, (2) guru dalam melaksanakan proses pembelajaran kebanyakan ceramah saja tanpa membimbing murid bagaimana cara berdiskusi dan bertukar pikiran dalam memecahkan masalah yang dihadapi. (3) guru kurang membimbing murid dalam mengembangkan dan mengenal secara utuh konsep-konsep dalam mata pelajaran PKn, sehingga dengan bimbingan guru tersebut murid dapat mengkontruksi pemikirannya untuk menemukan konsep-konsep pada mata pelajaran PKn lebih kompleks dan mudah untuk dipahami. (4) guru juga dalam mengajarkan PKn tidak memberikan keterhubungan antara materi dengan fenomena yang ada di lingkungan sekitar murid.

Untuk mendukung informasi tersebut diatas peneliti mencocokkan dengan dokumen nilai ternyata tampak bahwa pada umumnya murid kurang memahami konsep tersebut, hal ini terlihat dari ketidak mampuan murid dalam menjabarkan secara kompleks mengenai konsep yang benar, jadi untuk mengatasi masalah tentang pemahaman konsep didalam mata pelajaran PKn maka dipandang perlu untuk memilih metode dan bagai mana proses pelaksanaan metode tersebut dalam pembelajaran, sehingga dapat ditelaah dengan baik oleh guru maupun murid, karena terkadang didalam menyelesaikan suatu masalah di perlukan komunikasi dua arah agar permasalahan lebih mudah dipecahkan dan dapat diterima oleh semua pihak baik guru maupun murid melalui cara pengajaran metode yang baik. Sehingga pantaslah metode diskusi sebagai metode yang tepat dalam meningkatkan hasil belajar murid pada mata pelajaran PKn.

Berdasarkan hasil temuan, bahwa penjabaran konsep yang kurang baik akan berimplikasi pada rendahnya peningkatan hasil belajar pada mata pelajaran PKn, itu dibuktikan dengan $20 \%$ murid memperoleh ketuntasan belajar dalam nilai ujian mid semester atau 30 orang murid hanya 6 orang yang mendapatkan nilai 7 dengan nilai rata-rata kelas $58.66 \%$ artinya masih sangat kurang apalagi bila dibandingkan dengan standar ketuntasan peneliti yaitu $80 \%$ murid mendapatkan nilai 70 . Jadi, jika masalah tersebut tidak diatasi dengan metode dan tindakan yang tepat maka akan berdampak buruk bagi murid. Berdasarkan latar belakang tersebut, maka rumusan masalah dalam penelitian ini adalah: 
a. Apakah proses pelaksanaan pembelajaran dengan menggunakan metode diskusi Pada Mata Pelajaran PKn Tentang Menghargai dan Menaati Keputusan Bersama di Kelas VII SMP Negeri 3 Palopo Kota Palopo.

b. Bagaimanakah Metode diskusi dapat meningkatkan hasil belajar murid Pada Mata Pelajaran PKn Tentang Menghargai dan Menaati Keputusan Bersama di Kelas VII SMP Negeri 3 Palopo Kota Palopo.

\section{Metode Penelitian}

Pendekatan yang dipilih atau digunakan dalam pelaksanaan penelitian ini adalah pendekatan kualitatif. Pendekatan ini dipilih untuk mendeskripsikan aktivitas murid dalam pelaksanaan tindakan pembelajaran. Jenis penelitian yang digunakan adalah penelitian tindakan kelas yang bersifat deskriptif. Menurut Masnur Muslich (2009: 10) bahwa "PTK bertujuan untuk memperbaiki dan meningkatkan kualitas pembelajaran serta membantu memberdayakan guru dalam memecahkan masalah pembelajaran disekolah" sehingga peneliti menganggap penelitian dengan pendekatan kualitatif dengan menggunakan jenis penelitian tindakan kelas sangat cocok untuk dapat dipergunakan oleh guru dalam menyelesaikan masalah yang terjadi didalam kelas pada umumnya. Termasuk untuk dapat mempermudah penelitian yang peneliti angkat dengan judul meningkatkan hasil belajar murid dengan menggunakan metode diskusi dikelas VII SMP Negeri 3 Palopo Kota Palopo.

\section{Setting dan Subyek Penelitian}

Penelitian akan dilaksanakan di SMP Negeri 3 Palopo, Kota Palopo. Sekolah ini terdiri dari 16 kelas dengan jumlah murid 591 orang. Pelaksanaan penelitian direncanakan pada FebruariApril di semester genap tahun pelajaran 2015/2016.

Subyek dari penelitian ini adalah murid kelas VII SMP Negeri 3 Palopo Kota Palopo, dengan jumlah murid 40 yang terdiri dari 15 orang laki-laki dan 25 orang perempuan yang aktif dan terdaftar pada semester genap tahun ajaran 2015/2016 dengan sasaran utama meningkatkan hasil PKn melalui metode diskusi.

Peneliti memilih murid kelas VII sebagai objek penelitian karena berdasarkan pertimbangan: (1) Masih ditemukan murid yang mengalami kesulitan dalam memahami konsep-konsep pada mata pelajaran PKn, (2) di sekolah ini belum pernah dilakukan penelitian yang menggunakan metode diskusi, (3) Adanya dukungan kepala sekolah dan guru terhadap pelaksanaan penelitian ini, (4) Adanya variasi murid, dilihat dari status sosial, pendidikan, dan pekerjaan orang tua, dan (5) Tingkat perkembangan kognitif murid kelas VII SMP sudah dapat belajar menarik kesimpulan dari apa yang dilihat dan didengar.

\section{Desain Penelitian}

Penelitian ini menggunakan rencana penelitian tindakan kelas (Action Research Classroom) yaitu rencana penelitian berdaur ulang (siklus) hal ini mengacu kepada Kemmis dan Mc Taggart (Latri, 2003 : 21) proses penelitian tindakan merupakan sebuah siklus atau proses daur ulang yang terdiri dari empat aspek fundamental diawali dari aspek pengembangan perencanaan kemudian melakukan tindakan sesuai rencana, Observasi/pengamatan terhadap tindakan, dan diakhiri dengan melakukan refleksi, perenungan, pikiran dan evaluasi. 


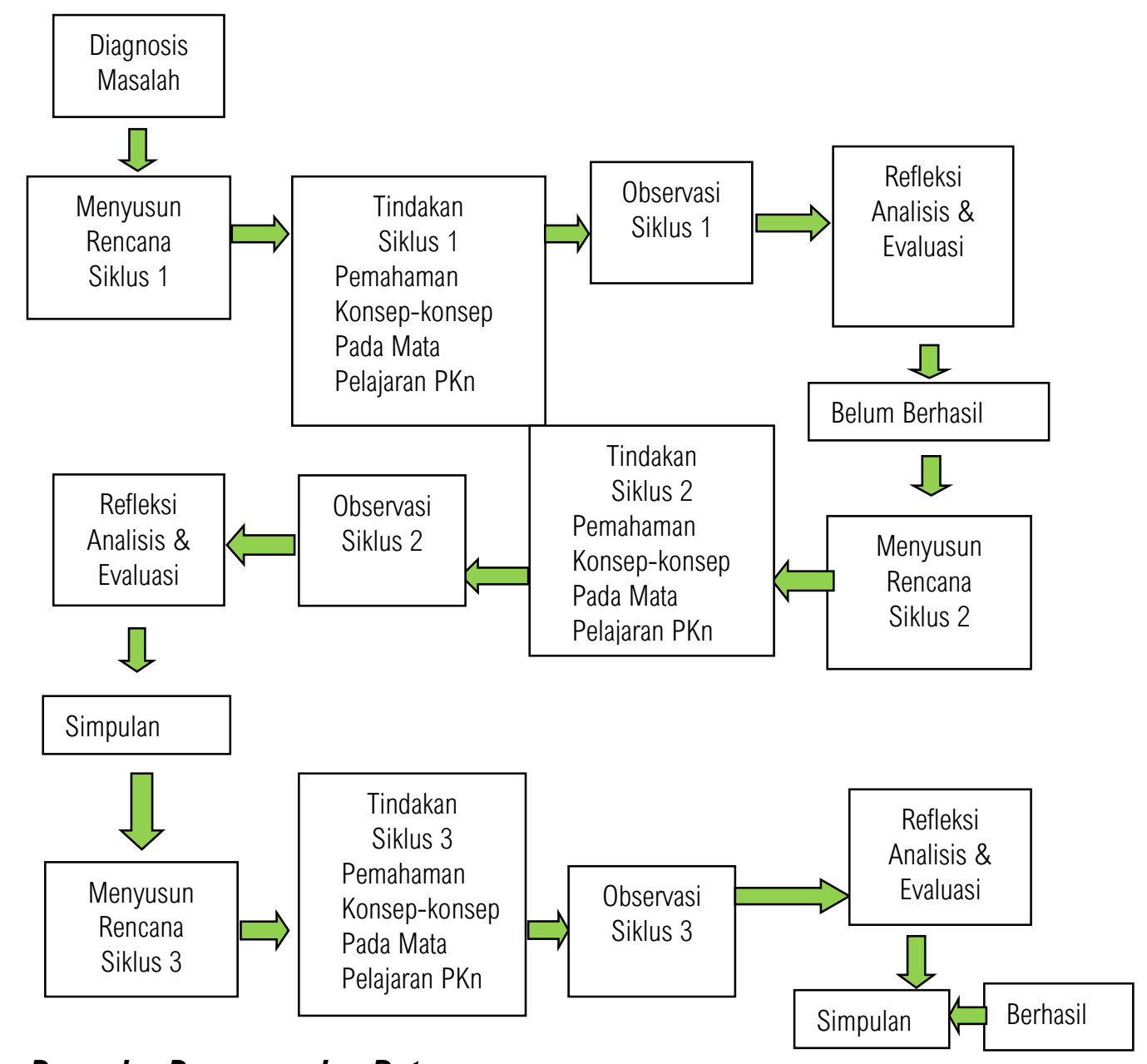

\section{Teknik dan Prosedur Pengumpulan Data}

Untuk mengumpulkan data dalam penelitian ini dilakukan dengan tes, angket, wawancara, pengamatan, dan catatan lapangan. Tes dilakukan untuk mengumpulkan informasi tentang kemampuan murid dalam pembelajaran konsep menghargai dan menaati keputusan bersama. Tes dilaksanakan pada awal penelitian, pada akhir setiap tindakan, dan pada akhir setelah diberikan serangkaian tindakan. Wawancara yang dimaksud untuk menggali kesulitan murid dalam pembelajaran konsep menghargai dan menaati keputusan bersama, yang mungkin sulit diperoleh dari hasil pekerjaan murid maupun melalui pengamatan. Pengamatan dilaksanakan oleh orang yang terlibat aktif dalam pelaksanaan tindakan yaitu guru yang mengajar di kelas VII dan teman sejawat. Pada pengamatan ini digunakan untuk mencatat hal-hal yang dianggap penting. Catatan lapangan memuat hal-hal penting yang terjadi selama pembelajaran berlangsung yang dapat digunakan untuk melengkapi data yang tidak terekam dalam lembar observasi.

\section{Hasil Penelitian}

Kegiatan pelaksanaan awal penelitian yang tepatnya pada hari Kamis, Tanggal 7 Juni 2015 peneliti mengadakan kunjungan ke SMP Negeri 3 Palopo yang menjadi tempat untuk mengadakan penelitian. Tujuan kunjungan ini adalah untuk melakukan koordinasi dengan guru dan kepala sekolah agar peneliti dapat diberikan izin untuk melakukan penelitian dan mengkoordinasikan jadwal yang akan dilakukan selama meneliti. Dalam kunjungan tersebut peneliti berkoordinasi dengan kepala sekolah tentang apa yang menjadi kendala didalam pembelajaran khusus pada mata pelajaran PKn, kemudian kepala sekolah menyerahkan 
sepenuhnya kepada guru kelas VII yang akan menjadi subyek penelitian. Berdasarkan hasil observasi dan diskusi dengan guru kelas VII SMP Negeri 3 Palopo Kota Palopo ditemukan data sebagai berikut: 1. Data dari hasil mid semester rata-rata penguasaan murid hanya mencapai $58,66 \%$ dengan ketuntasan belajar $20 \%$. 2. Data proses pembelajaran, guru mendominasi pembelajaran (single actor) sehingga mengakibatkan kurangnya aktifitas belajar murid.

Berdasarkan pemaparan masalah diatas peneliti menemukan penyebab rendahnya proses dan hasil pembelajaran pada mata pelajaran PKn yang tidak lain disebabkan penyajian materi dengan metode ceramah dan cenderung memaksa murid untuk menghafal materi, sehingga pembelajaran PKn diajarkan dengan kondisi pembelajaran yang tidak menyenangkan murid, baik bekerjasama secara individu atau kelompok.

Berdasarkan temuan diatas, peneliti bersama guru kelas VII bermaksud melakukan suatu proses perbaikan yang diharapkan mampu meningkatkan hasil pembelajaran PKn murid kelas VII SMP Negeri 3 Palopo Kota Palopo. Adapun hal yang disepakati yaitu melaksanakan pembelajaran PKn dengan menggunakan metode diskusi, yang terdiri dari tiga siklus.

\section{Siklus I}

\section{Perencanaan Siklus I}

Langkah pembelajaran diawali dengan menyamakan persepsi antara peneliti, sekolah dan guru SMP Negeri 3 Palopo Kota Palopo tentang bentuk penerapan metode diskusi yang akan digunakan dalam pembelajaran

1. Menyusun rancangan tindakan penelitian yang menggunakan metode diskusi.

2. Menentukan strategi pelaksanaan penilaian yang menggunakan metode diskusi yang efektif sehingga dapat meningkatkan hasil belajar murid dalam bidang studi PKn.

3. Melakukan diskusi balikan untuk mencari kelemahan yang dilakukan selama pembelajaran yang menggunakan metode diskusi

4. menyusun rencana pembelajaran untuk tindakan Siklus I.

5. Menyiapkan bahan pelajaran dan model tempat duduk yang akan digunakan dalam pembelajaran dengan menerapkan metode diskusi

6. Menyusun rambu-rambu instrumen data keberhasilan guru maupun instrumen data kemajuan hasil dan aktivitas belajar, berupa format observasi, tes, dan persiapan berupa rekaman foto pelaksanaan tindakan.

7. Peneliti dan pengamat mengadakan latihan bersama bagaimana mengimplementasikan rencana pembelajaran pada siklus I sebelum dilaksanakannya tindakan.

\section{Pelaksanaan Tindakan Siklus I}

Pelaksanaan tindakan Siklus I dilaksanakan pada hari Senin tanggal 1 Juli 2015 jam pelajaran 09.15-11.00. Dalam pelaksanaan penelitian siklus ini yang bertindak sebagai pengajar adalah peneliti sedangkan yang bertindak sebagai observer adalah teman sejawat.

Adapun pelaksanaan pembelajaran diawali Guru mengucapkan salam dan memimpin doa sebelum memulai pelajaran, serta mengabsen kehadiran murid, guru membagi murid dalam 5 kelompok yang tiap kelompok beranggotakan 6 orang, setelah murid terbagi dalam 5 kelompok kemudian mengberikan tugas diskusi yang homogen dan memebagi tugas kelompok yang terdiri atas mederator, notulen, penyaji dan anggota didalam kelompok.

Guru didalam melaksanakan pembelajaran disesuaikan dengan RPP yang telah disusun dengan menggunakan metode diskusi, setelah itu guru memeriksa segala kesiapan yang dianggap mempengaruhi kelancaran diskusi dan menjalankan prosedur berdiskusi yang baik, 
sehingga memudahkan murid didalam berdiskusi, kemudian menjalaskan secara umum tentang pokok bahasan yang akan dibahas yakni tentang menghargai dan menaati keputusan bersama pada sub pokok bahasan tata tertib sekolah. Kemudian guru menunjuk secara acak kelompok mempersentasekan pokok bahasan yang dibahas kemudian dengan arahan dan bantuan guru, murid berdiskusi dengan aturan main diskusi yang telah ditetapkan. Dengan memperhatikan iklim menyenangkan, tidak tegang dan tidak saling menyudutkan.

Murid melakukan diskusi yang dipandu oleh guru dan memberikan kesempatan kepada murid kesempatan yang sama dalam mengemukakan pendapat, gagasan dan ide-idenya setelah itu murid secara perkelompok melaporkan hasil diskusi setelah diskusi berakhir guru mengadakan evaluasi secara individu kemudian melaksanakan penskoran hasil evaluasi murid dan diakhir pelaksanaan pembelajaran guru bersama murid menyimpulkan materi pembelajaran.

Berdasarkan hasil evaluasi yang memberikan pelaksanaan tindakan siklus I lebih baik dibanding dengan skor awal murid yang belum mencapai target minimal yang telah ditetapkan yakni $80 \%$. Dimana dari pelaksanaan tindakan siklus I yang masih jauh dari yang diharapkan yaitu murid yang mendapatkan nilai 100 belum ada, namun yang sudah mememperoleh ketuntasan belajar mencapai $26.66 \%$ dengan nilai rata-rata $60 \%$ meningkat $6.66 \%$ dari hasil tes awal yang diambil dari sekolah yaitu dengan rata-rata kelas 58.66 dan ketuntasan belajar $20 \%$. Nilai tersebut memperlihatkan adanya peningkatan hasil belajar murid dibangdingkan hasil belajar murid sebelumnya.

\section{Observasi}

Hal-hal yang diobservasi pada pelaksanaan siklus I adalah metode diskusi, dan lembar observasi guru serta lembar observasi murid dalam kegiatan pembelajaran. Berdasarkan hasil observasi pelaksanaan tindakan siklus I, dapat dijelaskan bahwa pembelajaran belum mencapai hasil maksimal walaupun sudah mengalami peningkatan dibandingkan dengan pembelajaran sebelumnya.

Dari seluruh rangkaian pembelajaran ada beberapa temuan observer (Teman sejawat). Adapun temuan hasil observasi guru (peneliti) yang dilakukan pada siklus I adalah sebagai berikut:

1. Guru tidak membangun dan mengaitkan tentang konsep yang ingin dicapai dengan pertanyaan-pertanyaan yang memancing pemahaman awal murid terhadap model pembelajaran diskusi mengenai pokok bahasan menghargai dan menaati keputusan bersama.

2. Pembagian kelompok tidak berjalan efektif, karena masih ada murid yang kurang perhatian terhadap penting memberikan tanggapan atas kelompok-kelompok yang memberikan saran.

3. Guru terlalu mendominasi jalannya diskusi.

4. Guru belum menggunakan waktu secara efisien, sehingga pembelajaran yang direncanakan tidak sesuai dengan yang dilaksanakan.

Sedangkan hasil observasi murid menunjukan bahwa murid merasa diperhatikan oleh guru karena selalu berkeliling untuk memeriksa temuan murid. Murid masih kurang berani bertanya apabila ada hal-hal yang kurang dimengerti.

Dari hasil observasi terhadap aktivitas guru pada siklus 1 kemampuan guru dalam mengajarkan materi menghargai dan menaati keputusan bersama pada sub pokok bahasan tata tertib sekolah dengan menggunakan metode diskusi berkategori sedang. Hal ini terlihat 
dari terpenuhinya indikator-indikator kinerja yang ada dalam lembar observasi guru. Jika dipersentasekan secara keseluruhan bahwa indikator yang berhasil dicapai guru berkategori sedang yaitu 7 (53.33\%) dari12 indikator yang harus dicapai. Sedangkan yang belum tercapai adalah $5(16.66 \%)$ indikator. Sementara lembar observasi yang ditujukan kepada murid juga menunjukan pencapaian indikator dengan kategori sedang yaitu 8 (66.66\%) dari 12 indikator. Sedangkan yang belum tercapai adalah 4 (33.33\%).

\section{Refleksi}

Berdasarkan data tes/evaluasi, observasi dan wawancara yang telah dilaksanakan pada pelaksanaan tindakan siklus I belum mencapai target indikator keberhasilan yang ditetapkan yaitu $80 \%$ atau lebih dari seluruh murid yang mengikuti kegiatan pembelajaran serta penguasaan materinya minimal mencapai $80 \%$ dengan nilai rata-rata 70 . Maka guru/peneliti dan observer/pengamat mengadakan refleksi dengan maksud memperbaiki pembelajaran berikutnya.

Dari hasil refleksi tersebut, maka peneliti mengadakan perbaikan berdasarkan bimbingan dan hasil observasi dari teman sejawat selaku observer pada siklus I untuk tindakan yang akan dilaksanakan pada siklus II, yakni sebagai berikut:

1. Guru mengkomunikasikan pokok bahasan dengan pertanyaan-pertanyaan yang memancing pemahaman awal murid terhadap model pembelajaran diskusi dan mengenai pokok bahasan menghargai dan menaati keputusan bersama.

2. Mengamati tidak berlebihan agar tidak mengalami kesulitan dan memberikan arahan dan bimbingan dengan cara mengajukan pertanyaan.

3. Melakukan pembagian kelompok heterogen kemampuannya dan mengamati proses diskusi dalam setiap kelompok.

4. Guru mestinya tidak mendominasi jalannya diskusi tetapi menyerahkan sepenuhnya kepada murid.

5. Guru baiknya menggunakan waktu secara efisien, sehingga pembelajaran yang direncanakan tidak sesuai dengan yang dilaksanakan.

6. Guru lebih membimbing murid agar berani mengemukakan tanggapan atau gagasan.

\section{Siklus II}

\section{Perencanaan Siklus /I}

Dengan berbekal hasil refleksi dari kegiatan pembelajaran yang dilaksanankan pada siklus I, maka dalam melaksanakan kegiatan pembelajaran pada siklus II dengan harapan pada pembelajaran siklus II hasil belajar murid akan lebih meningkat. Selanjutnya pada perencanaan tindakan sislus II peneliti melakukan hal-hal sebagai berikut:

1. Menyusun rencana pelaksanaan pembelajaran siklus II.

2. Membagi kelompok murid dengan kelompok yang berkemampuan heterogen dan membagi tugas murid dalam kelompok seperti siapa yang akan menjadi moderotor, penyaji dan notulen serta anggota dalam kelompok

3. Menyusun rambu-rambu untuk mengetahui gambaran pelaksanaan proses pembelajaran, meliputi: lembar observasi kegiatan guru, lembar observasi kegiatan murid, lembar wawancara dengan murid dan dokumentasinya.

4. Mengamati tidak berlebihan agar murid tidak canggung didalam proses diskusi. 


\section{Pelaksanaan Tindakan}

Tindakan siklus II akan dilaksanakan pada hari Sabtu, 7 Juli 2015 mulai dari pukul 09.15 11.00 WITA. Pada siklus ini yang bertindak sebagai guru adalah peneliti sedangkan yang bertindak sebagai observer adalah teman sejawat. Pelaksanaan tindakan siklus II dengan materi lanjutan siklus I yaitu "menghargai dan menaati keputusan bersama pada sub pokok bahasan tata tertib sekolah".

Kegiatan pembelajaran diawali Guru mengucapkan salam dan memimpin doa sebelum memulai pelajaran, mengecek kehadiran murid, berdo'a dan membagi murid dalam 5 kelompok yang tiap kelompok beranggotakan 6 orang, serta menjelaskan manfaat dan tujuan pembelajaran yang akan dicapai.

Kemudian kegiatan pembelajaran dimulai dengan guru memeriksa segala kesiapan yang dianggap mempengaruhi keancaran diskusi, setelah itu guru menjelaskan materi yang akan diajarkan kepada murid sebelum didiskusikan, kemudian guru membagikan tugas untuk memdiskusi konsep pembelajaran yakni mengenai tata tertib sekolah, dan memberikan waktu kepada murid untuk mendiskusikannya didalam kelompoknya masing-masing sebelum didiskusikan oleh semua kelompok didalam kelas.

Dalam memulai proses diskusi kelas guru memilih kelompok secara acak yang akan mempersentasekan hasil diskusi, kemudian diskusi kelaspun dimulai dengan memnyerahkan sepenuhnya diskusi kepada muridi, dan masing-masing kelompok memberikan tanggapan dan mempersentasekan hasil diskusinya mengenai konsep menghargai dan menaati keputusan bersama pada sub pokok bahsan tata tertib sekolah yang diberikan oleh guru.

Kemudian kelompok yang mempersentasekan hasil diskusi didalam kelas memberikan tanggapan dan melibatkan semua peserta diskusi dalam menyepakati hasil diskusi yang dihasilkan serta kelompok yang ditunjuk guru untuk mempersentasekan diskusi memberikan kesimpulan terhadap apa yang didiskusikan.

Diakhir diskusi guru memberikan motivasi terhadap kelompok yang tampil dan semua kelompok yang sudah ikut berperan aktif dalam diskusi, selanjutnya pada saat pembelajaran berakhir peneliti mengadakan klarifikasi tiap kelompok untuk memberikan kesimpulan materi dan diakhir kegiatan dilakukan tes/evaluasi yang dilaksanakan untuk mengetahui keberhasilan pelaksanaan tindakan siklus II.

Berdasarkan hasil evaluasi yang diberikan pada pelaksanaan tindakan siklus II, memberikan hasil yang lebih baik dibanding dengan skor awal murid walaupn belum mencapai target minimal yang telah ditetapkan. Dimana pelaksanaan tindakan siklus II, hasil belajar murid adalah sebagai berikut, murid belum ada yang mendapatkan nilai 100 , namun pembelajaran didalam siklus II sudah meningkat hal ini dibuktikan dengan nilai rata-rata siklus II yaitu $66 \%$ meningkat $6 \%$ dari rata-rata sebelumya pada siklus I yaitu $60 \%$ dan ketuntasan belajar meningkat disiklus II yaitu $53.33 \%$ meningkat $26.67 \%$, dari ketuntasan sebelumnya disiklus I yaitu 26.66. Nilai tersebut memperlihatkan adanya peningkatan hasil belajar murid dibangdingkan hasil belajar murid sebelumnya. Walaupun belum mencapai target indikator $80 \%$ dari seluruh murid telah memperoleh nilai minimal 70 .

\section{Observasi Siklus II}

Adapun tujuan dari pelaksanaan observasi pada siklus II ini untuk mengetahui pelaksanaan pembelajaran apakah telah sesuai dengan perencanaan. Secara umum hasil tes/evaluasi dan observasi pada siklus II ini mengalami peningkatan dibandingkan dengan siklus I, hal ini 
terlihat pada hasil observasi guru dan murid. Hasil observasi terhadap guru (peneliti) menunjukan bahwa:

1. Guru sudah dapat membangun dan mengkomunikasikan pokok bahasan dengan pertanyaan-pertanyaan yang memancing pemahaman awal murid terhadap model pembelajaran diskusi dan mengenai pokok bahasan menghargai dan menaati keputusan bersama.

2. Guru tidak memperketat pengawasan terhadap jalannya diskusi

3. Pembagian kelompok sudah berjalan efektif,

4. Guru tidak lagi mendominasi jalannya diskusi.

5. Guru belum menggunakan waktu secara efisien, sehingga pembelajaran yang direncanakan tidak sesuai dengan yang dilaksanakan.

Sedangkan hasil observasi murid menunjukan hal-hal sebagai berikut:

1. Murid sudah lebih leluasa didalam menyampaikan gagasannya dalam diskusi

2. Murid sudah bekerjasama dengan baik terhadap sesama teman kelompoknya

3. Murid sudah mampu mengerjakan tugas yang diberikan

4. Murid belum mampu memimpin sepenuhnya jalannya diskusi kelas.

Dari hasil observasi terhadap aktivitas guru pada Siklus II kemampuan guru dalam mengajarkan materi menghargai dan menaati keputusan pada sub pokok bahasan tata tertib sekolah dengan menggunakan menggunakan metode diskusi berkategori tinggi. Hal ini terlihat dari terpenuhinya indikator-indikator kinerja yang ada dalam lembar observasi guru. Jika dipersentasekan secara keseluruhan bahwa indikator yang berhasil dicapai guru berkategori tinggi yaitu 10 (83.33\%) dari 12 indikator. Sementara lembar observasi yang ditujukan kepada murid juga menunjukan pencapaian indikator dengan kategori baik yaitu 9 (75\%) dari 12 indikator.

\section{Refleksi}

Untuk mendapatkan balikan yang tepat dari pelaksanaan pembelajaran pada siklus II, peneliti dan pengamat merefleksi semua data yang ditemukan dalam lembar observasi aspek guru dan murid selama proses pembelajaran. Selain itu hasil tes formatif yang dijadikan bahan balikan. Hasil refleksi dari peristiwa-peristiwa yang terjadi pada tindakan siklus II. Menurut observer guru sudah melaksanakan pembelajaran yang sesuai dengan metode diskusi, namun masih ada beberapa hal kekurangan-kekurangan, maka akan disusun upaya perbaikan untuk tindakan siklus III, yakni sebagai berikut:

1. Penguasaan kelas harus lebih ditingkatkan lagi agar pembelajaran lebih optimal

2. Guru tidak boleh menyerahkan sepenuhnya diskusi kepada murid namun mesti bekerja sama dengan guru dalam pelaksanaan atau jalanya diskusi agar diskusi lebih fokus dan tidak melebar.

3. Guru harus membimbing murid dalam mempersentasekan dan menanggapi hasil diskusi kelompok.

4. Lebih intensif menciptakan suasana pembelajaran yang menyenangkan.

\section{Siklus III}

\section{Perencanaan Siklus III}

Berdasarkan hasil refleksi pada tindakan siklus II, maka dalam pelaksanakan kegiatan pembelajaran pada siklus III peneliti kembali merumuskan langkah-langkah yang harus ditempuh. Langkah-langkah tersebut ialah: 
1. Menyusun rencana pelaksanaan pembelajaran untuk tindakan siklus III (rencana pelaksanaan pembelajaran terlampir).

2. Menyiapkan lembar soal untuk melaksanakan evaluasi dengan tingkat kesukaran yang lebih tinggi dari evaluasi siklus II (tes evaluasi terlampir)

3. Menyusun rambu-rambu untuk mengetahui gambaran pelaksanaan proses pembelajaran, meliputi lembar observasi kegiatan guru, lembar observasi kegiatan murid, lembar wawancara dan dokumentasi.

\section{Pelaksanaan Siklus III}

Tindakan siklus III akan dilaksanakan pada hari sabtu, 15 Agustus 2015 mulai dari pukul 09.15 - 11.00 WITA. Pembelajaran tindakan siklus III berlangsung selama 105 menit. Pada siklus ini yang bertindak sebagai observer adalah teman sejawat. Kelemahan dan kekurangan akan dierbaiki pada siklus III begitupun keberhasilan disiklus II akan dipertahankan dan dikembngkan disiklus III. Materi pelaksanaan pembelajaran yakni pokok bahasan sama namun sub pokok bahasan yang berbeda yakni "menghargai dan menaati keputusan bersama pada sub pokok bahasan tata tertib kelas".

Kegiatan kegiatan pembelajaran yang dilaksanakan pada siklus ini diawali dengan mengucapkan salam, mendata kehadiran murid, mempersiapkan perlengkapan yang dibutuhkan didalam pembelajaran, berdo'a, dan menyampaikan tujuan pembelajaran serta melakukan apersepsi dengan melakukan tanya jawab mengenai materi yang telah dipelajari.

Selanjutnya kegiatan pembelajaran dibagi menjadi 5 kelompok yang masing-masing beranggotakan 6 orang yang heterogen yang kelompoknya sama dengan siklus II. Kemudian peneliti menjelaskan materi tentang menghargai dan menaati keputusan bersama pada sub pokok bahasan tata tertib kelas, kemudian guru dan murid menyepakati hal apa yang didiskusikan agar murid dan guru dapat bekerjasama dalam diskusi, setelah terjadi kesepakatan diskusipun dimulai dengan guru menunjuk secara acak yang akan mempersentasekan membawa materi diskusi, kemudian guru memberikan kesempatan untuk mendiskusikan bersama kelompok kecil di masing-masing kelompoknya sebelum didiskusikan secara umum dalam diskusi kelas.

Selanjutnya diskusi kelas dilakukan oleh kelompok yang telah ditunjuk oleh guru secara acak, diskusi dilakukan dengan arahan guru kemudian kelompok yang ditunjuk mempersentasekan hasil diskusi kelompoknya, kemudian kelompok-kelompok lain memberikan tanggapan atas apa yang mereka dapatkan didalam kelompok mereka masingmasing, guru pun tetap menuntun murid dalam berdiskusi agar konsep yang ingin dicapai tidak melenceng, serta memeberikan penguatan terhadap murid yang melakukan persentase dan yang memberikan tanggapan. Kemudian kelompok penyaji menyepakati secara bersama hasil diskusi yang dilakukan didalam kelas mengenai konsep menghargai dan menaati keputusan bersama pada sub pokok bahasan tata tertib kelas.

Dalam akhir pembelajaran peneliti mengadakan klarifikasi tiap kelompok untuk memberikan kesimpulan materi, dan akhir kegiatan dilakukan tes/evaluasi yang dilaksanakan untuk mengetahui keberhasilan pelaksanaan tindakan siklus III.

Berdasarkan hasil evaluasi yang diberikan pelaksanaan tindakan siklus III telah mencapai target yang telah ditetapkan. Dimana dari pelaksanaan tindakan siklus III, yaitu murid yang telah mendapatkan nilai 100 hanya 3 orang murid. pembelajaran didalam siklus III sudah sangat meningkat hal ini dibuktikan dengan nilai rata-rata siklus III yaitu $82.33 \%$ meningkat $16 \%$ dari rata-rata sebelumya pada siklus II yaitu $66.33 \%$ dan ketuntasan belajar meningkat 
disiklus III yaitu 100\% meningkat $46.67 \%$ dari ketuntasan sebelumnya disiklus II yaitu 53.33\%. Nilai tersebut memperlihatkan adanya peningkatan hasil belajar murid dibangdingkan hasil belajar murid sebelumnya. Dan seluruh murid sudah mampu mencapai target indikator $80 \%$ dari seluruh murid telah memperoleh nilai minimal 70 .

Pada akhir pembelajaran pembelajaran guru dan murid bersama-sama menyimpulkan materi pembelajaran dan guru memberikan nasehat kepada dan memotivasi kepada murid agar lebih giat dan rajin belajar serta mampu bekerjasama dengan baik pada dengan sesama teman.

\section{Observasi Siklus III}

Pada pelaksanaan tindakan siklus III secara umum hasil tes/evaluasi dan observasi sudah mencapai target yang telah ditetapkan sebelumnya. Hal ini terlihat dari hasil observasi terhadap guru dan murid. Hasil observasi terhadap guru adalah sebagai berikut:

1. Penguasaan kelas sudah berjalan dengan optimal sehingga pembelajaran berlangsung tertib

2. Guru dan murid sudah bersinergi dalam diskusi sehngga menghasilkan diskusi yang sangat menyengkan dan membuka wawasan murid

3. Guru sudah membimbing murid secara individu dan kelompok yang mengalami kesulitan dalam pembelajaran

4. Motivasi yang diberikan kepada murid telah optimal hal ini ditandai ketika pembelajaran berlangsung tidak ada lagi murid yang mengacuhkan pembelajaran.

Hasil observasi terhadap kegiatan murid selama proses pembelajaran berlangsung menunjukkan bahwa murid sudah mampu bekerjasama dalam kelompoknya masing-masing sehingga mengalami peningkatan hasil belajar. Murid juga telah memperhatikan penjelasan guru dangan penuh perhatian. Semua murid telah berperan aktif dalam pembelajaran hal ini dapat dilihat pada saat diskusi kelompok. Murid sudah mampu memimpim jalan diskusi dan mengetahui perangkat dalam diskusi, tugas dan fungsinya.

\section{Refleksi Siklus III}

Berdasarkan hasil tes/evaluasi dan observasi serta hasil wawancara pelaksanaan siklus III telah menunjukan peningkatan yang maksimal.pada tahap ini peneliti bersama observer secara kolaborasi mengamati dan mengevaluasi hasil belajar murid pada akhir pembelajaran yang sedang berlangsung.

Berdasarkan paparan data di atas dapat disimpulkan bahwa pembelajaran pada siklus III telah berhasil mencapai target yang telah ditetapakan yaitu $80 \%$ murid mendapatkan nilai 70 , pencaian materi yang diharapkan sudah sanagat maksimal ini dibukatikan dalam observasi dan wawancara dengan guru kelas VII SMP Negeri 3 Palopo Kota Palopo bahwa dalam tindakan siklus III pembelajaran sudah menciri khaskan penggunaan metode diskusi, walaupun masih ada yang perlu diperhatikan guru/peneliti yakni bimbingan harus lebih intensif lagi, penguasaan kelas perlu ditingkatkan dan pemanfaatan waktu harus lebih efisien.

\section{Pembahasan}

Hasil penelitian yang terdiri dari aktifitas murid, guru dan proses belajar dalam peningkatan hasil belajar PKN tentang konsep menghargai dan menaati keputusan bersama dua sub pokok bahasan yakni tata tertib sekolah dan tata tertib kelas dengan menggunakan metode diskusi yang terdiri dari tiga tahapan, yaitu persiapan pembelajaran, kegiatan inti dan kegiatan akhir. 
murid mengerjakan soal secara individu, pemeriksaan hasil tes, dari siklus pertama, kedua, dan ketiga mengalami peningkatan yang signifikan.

Dari hasil observasi terhadap aktivitas guru pada siklus 1 kemampuan guru dalam mengajarkan konsep menghargai dan menaati keputusan bersama dengan menggunakan metode diskusi berkategori sedang. Hal ini terlihat dari terpenuhinya indikator-indikator kinerja yang ada dalam lembar observasi guru. Jika dipersentasekan secara keseluruhan bahwa indikator yang berhasil dicapai guru berkategori sedang yaitu $7(53.33 \%)$ dari 12 indikator yang harus dicapai. Sedangkan yang belum tercapai adalah $5(41.66 \%)$ indikator. Sementara lembar observasi yang ditujukan kepada murid juga menunjukan pencapaian indikator dengan kategori sedang yaitu $8(66.66 \%)$ dari 12 indikator. Sedangkan yang belum tercapai adalah 4 (33.33\%) indikator.

Guru dalam menyampaikan proses pembelajaran PKn pada konsep menghargai dan menaati keputusan bersama dalam sub pokok bahasan tata tertib sekolah dengan menggunakan metode diskusi pada tindakan Siklus I masih terdapat beberapa kekurangan diantaranya sebagai berikut: 1) Guru terlalu aktif didalam diskusi sehingga konsep pembelajaran kurang berkembang, 2) Guru kurang memotivasi murid agar memberanikan diri dalam mengemukakan pendapatnya mengenai jawaban atau dalam mengeluarkan pendapat lain, 3) Guru kurang mengontrol murid dalam berdiskusi sehingga masih ada murid yang tidak berperan aktif dalam kelompoknya, 4) Waktu pembelajaran masih tidak tepat waktu. Hal ini disebabkan pengorganisasian disaat berdiskusi kurang efesien.

Hal Ini sejalan dengan pendapat Zarkasi (2009: 97) yang mengemukakan bahwa:

Metode diskusi tidak sekedar perdebatan antara murid atau perdebatan antara guru dan murid. Diskusi tidak hanya terdiri dari mengajukan pertanyaan - pertanyaan dan menerima jawaban, diskusi ialah usaha seluruh kelas untuk mencapai pengertian disuatu bidang, memperoleh pemecahan bagi suatu masalah, menjelaskan sebuah ide, atau menentukan tindakan yang akan diambil.

Dari permasalahan diatas yang dikemukan diatas mengakibatkan hasil belajar murid belum mencapai target yang telah ditetapkan sebelumnya sehingga perlu adanya perbaikan dalam pembelajaran selanjutnya.

Berdasarkan tabel hasil tes/evaluasi tersebut, diperoleh data bahwa tingkat penguasaan murid terhadap materi rata-rata $60 \%$ atau meningkat $1.34 \%$ dari hasil tes awal yang diambil dari sekolah dimana penguasaan murid terhadap materi rata-rata hanya $58.66 \%$. Dari tabel dapat dilihat kemampuan murid, yang dikategorikan mampu sebanyak 8 orang yang memahami konsep menghargai dan menaati keputusan bersama pada sub pokok bahasan tata tertib sekolah dengan menggunakan metode diskusi dengan persentase $26.66 \%$, murid yang dikategorikan cukup sebanyak 15 orang dengan persentase $50 \%$, dan murid yang dikategorikan kurang sebanyak 6 orang dengan persentase 20\%. Serta murid yang dikategorikan kurang sekali sebanyak 1 orang dengan persentase 3.33\%. Dari data di atas nampak bahwa, belum berhasil pelaksanaan tindakan siklus I karena belum tercapai indikator keberhasilan yakni $80 \%$ murid mendapat nilai minimal 70 .

Hal ini menunjukkan bahwa bahwa pembelajaran pada siklus I belum berhasil dan harus dilanjutkan pada siklus II. Pada tindakan siklus II kegiatan guru mengalami peningkatan. berdasarkan hasil observasi yaitu dimana kekurangan pada siklus I sudah diperbaiki pada siklus II, guru memberikan keleluasaan kepada murid dalam memimpin jalannya diskusi, guru sudah mampu membagi kelompok dengan baik, namun yang terjadi pokok bahasan yang ingin 
dicapai tidak fokus karena murid dalam memimpin jalannya diskusi kurang tegas mengarahkan materi diskusi.

Berdasarkan hasil observasi dan wawancara yang dikemukakan sebelumnya, hasil belajar murid belum mencapai target yang telah ditetapkan sebelumnya sehingga perlu adanya perbaikan pembelajaran selanjutnya. Berdasarkan hasil tes yang dilakukan pada siklus II, diperoleh data bahwa tingkat penguasaan murid terhadap materi rata-rata $66.33 \%$ atau meningkat $6.33 \%$ dari hasil tes pada siklus I dimana penguasaan murid terhadap materi ratarata $60 \%$ (Nilai tes formatif siklus II terlampir).

Dari tabel menunjukkan bahwa dari 16 murid yang mampu memahami konsep menghargai dan menaati keputusan bersama pada sub pokok bahasan tata tertib dengan menggunakan metode diskusi dengan persentase 53.33\%, murid yang berkategori cukup 14 orang dengan persentase $46.66 \%$. nilai tersebut memperlihatkan adanya peningkatan hasil belajar murid dibandingkan dengan siklus I.

Dari hasil observasi terhadap aktivitas guru pada Siklus II kemampuan guru dalam mengajarkan materi menghargai dan menaati keputusan bersama pada sub pokok bahasan tata tertib sekolah dengan menggunakan metode diskusi berkategori tinggi. Hal ini terlihat dari terpenuhinya indikator-indikator kinerja yang ada dalam lembar observasi guru. Jika di persentasekan secara keseluruhan bahwa indikator yang berhasil dicapai guru berkategori tinggi yaitu $10(83.33 \%)$ dari 12 indikator. Sementara lembar observasi yang ditujukan kepada murid juga menunjukan pencapaian indikator dengan kategori baik yaitu 9 (75\%) dari 11 indikator. Pembelajaran konsep menghargai dan menaati keputusan bersama pada dua sub pokok bahasan tata tertib sekolah dan tata tertib kelas dengan menggunakan metode diskusi pada Siklus II ini mengalami keberhasilan dan mencapai kualifikasi Baik (B).

Dari uraian tersebut dapat disimpulkan bahwa pembelajaran siklus II belum mencapai target yang telah ditetapkan yakni $80 \%$ murid mendapatkan nilai 70 . Oleh sebab itu pembelajaran harus dilanjutkan kesiklus III. Pada pelaksanaan siklus III yang berdasarkan dari hasil observasi siklus III kegiatan guru dan murid sudah optimal yaitu sudah sesuai dengan langkah-langkah pembelajaran yang telah direncanakan sehingga kegiatan dapat terlaksana dengan baik. Dimana didalam pembelajaran siklus III menunjukkan adanya perubahan yang lebih baik dari yang sebelumnya karena semua langkah-langkah pembelajaran sudah sesuai dengan metode diskusi, yang mana apabila metode pembelajaran ini diterapkan dengan tepat maka akan terjadi perubahan baik dari segi proses maupun dari segi hasil pembelajaran. Hal ini karena kekurangan disiklus II sudah dapat dibenahi dengan baik yakni guru dan murid sudah dapat bersinergi dengan baik didalam berdiskusi sehingga hasil pembelajaran memperoleh hasil yang signifikan.

Berdasarkan hasil tes formatif yang dilaksanakan pada siklus III, diperoleh data bahwa tingkat penguasaan murid rata-rata $82.33 \%$ atau meningkat $16 \%$ dari hasil tes formatif pada siklus II dimana penguasaan materinya rata-rata 66.33\%. Adapun hasil yang diperoleh murid pada siklus III adalah $100 \%$ atau 30 orang memperoleh nilai $\geq 70$, hal ini dilihat dari murid yang berkategori sangat mampu berjumlah 17 orang dengan persentase $56.66 \%$, sedangkan murid yang berkategori mampu sebanyak 12 orang dengan persentase 40\%. Dan disertai dengan tercapainya seluruh indikator dalam observasi guru dan murid

Hal ini sejalan dengan pendapat Hermansyah (2008:1) yang menyatakan bahwa:

Diskusi hendak hasil tukar pikiran antara semua perangkat yang ada dalam diskusi yang meliputi guru dan murid,. Agar diskusi bisa produktif, dan tentunya akan tercipta suasana keramahan dan keterbukaan. Diskusi 
yang bermanfaat didasarkan atas rasa saling menghormati pendapat setiap orang yang hadir, sehingga nantinya akan berdampak signifikan terhadap proses dan hasil pembelajaran.

Berdasarkan argumentasi salah satu pakar diatas yang mendukung tentang keberhasilan metode diskusi yang disajikan, dan dilengkapi keberhasilan data proses serta data hasil diatas, maka pembelajaran pada siklus III ini telah tercapai dengan indikator yang ditetapkan yakni 80\% murid mendapatkan nilai 70 maka disimpulkan bahwa penerapan metode diskusi pada konsep menghargai dan menaati keputusan bersama pada dua sub pokok bahasan tata tertib sekolah dan tata tertib kelas di kelas VII SMP Negeri 3 Palopo memberikan dampak yang cukup signifikan terhadap peningkatan hasil belajar PKn.

\section{Kesimpulan}

Penggunaan medote diskusi dalam meningkatkan hasil belajar murid pada mata pelajaran PKn tentang menghargai dan menaati keutusan bersama kelas VII SMP Negeri 3 Palopo Kota Palopo, dilaksanakan melalui proses pembelajaran pada pokok bahasan menghargai dan menaati keputusan bersama yang dijabarkan dalam dua sub pokok bahasan yaitu tata tertib sekolah dan tata tertib kelas, yang kemudian dibagi menjadi tiga tahap kegiatan, yaitu kegiatan awal, kegiatan inti, dan kegiatan akhir. Dan pada kegiatan inti setiap siklus dilaksanakan sesuai dengan rencana pembelajaran yang telah disusun, yaitu, tahap persiapan, tahap pembagian kelompok yang hererogen dan pembagian tugas kelompok, tahap pelaksanaan diskusi, tahap menanggapi dan tahap pengambilan keputusan bersama, berdasarkan proses pembelajaran maka peneliti menyimpulkan bahwa metode diskusi pada mata pelajaran PKn tentang menghargai dan menaati keputusan bersama dilaksanakan dengan tahap-tahap yang telah dikemukakan diatas maka hasil belajar murid akan meningkat.

Hasil belajar murid pada mata pelajaran PKn terhadap materi menghargai dan menaati keputusan bersama dengan menggunakan metode diskusi kelas VII SMP Negeri 3 Palopo Kota Palopo menunjukkan bahwa data awal hasil belajar murid pada mata pelajaran PKn tentang menghargai dan menaati keputusan bersama yaitu memperoleh nilai awal 20\% anak yang memperoleh nilai $\geq 70$. Hal ini mengalami peningkatan pada siklus I naik dengan nilai $26,66 \%$ anak yang memperoleh nilai $\leq 70$. Selanjutnya disiklus II meningkat dengan nilai ketuntasan belajar sebesar $53,33 \%$ anak yang memperoleh nilai $\leq 70$, dan pada siklus III murid yang memperoleh niali $\leq 70$ meningkat dengan nilai $100 \%$. Berdasarkan nilai yang dicapai murid pada setiap akhir pembelajaran tersebut dari siklus I,II,II menunjukkan peninggkatan yang baik. $\mathrm{Hal}$ ini dapat diinterpretasikan bahwa murid sudah mengalami peningkatan hasil belajar PKN pada materi menghargai dan menaati keputusan bersama dengan baik.

Berdasarkan simpulan hasil penelitian dapat disarankan kepada para kepala sekolah, khususnya kepala sekolah SMP Negeri 3 Palopo Kota Palopo agar melibatkan staf pengajar yang bertugas di wilayah kerjanya untuk selalu berdiskusi bersama dalam membicarakan masalah yang muncul dalam pembelajaran dan mencari solusinya secara bersama demi meningkatkan proses dan hasil pembelajaran temasuk pembelajaran pada konsep-konsep PKn.

Selanjutnya, diharapkan kepada guru SMP yang akan mengajarkan PKn, sebaiknya menerapkan metode diskusi, karena mata pelajaran PKn sangat luas cakupannya sehingga mesti ada interaksi aktif dalam pembelajaran sehingga murid pun mudah dipahami. Diharapkan kepada guru didalam menggunakan metode diskusi didalam proses pembelajaran diharapkan tidak menanggalkan instrumen instrumen dalam melakukan diskusi agar diperoleh hasil yang maksimal. 


\section{Referensi}

Astuti, W. (2008). Pendidikan Kewarganegaraan. Jakarta: PT Permata Insan Madani.

Muslich, M. (2009). Penelitian Tindakan Kelas Itu Mudah. Jakarta: PT Bumi Aksara.

Rumiati, (2007). Pengembangan Pendidikan Kewarganegaraan. Jakarta: Direktorat Jenderal Pendidikan Tinggi Departemen Pendidikan Nasional

Sanjaya, W. (2009). Strategi Pembelajaran Berorientasi Standar Proses Pendidikan, Jakarta: Kencana

Syah, M. (2006). Psikologi Belajar, Jakarta: PT. Raja Grahindo Persada.

Samira, (2008). Peranan Pembelajaran PKn Dalam Meningkatkan Moral Murid di SMP, Makassar: Universitas Negeri Makassar

Zarkasi, F. (2009). Belajar Cepat dengan Diskusi. Surabaya: Indah Surabaya. 